ISSN 1896-8147

DOI: http://dx.doi.org/10.21784/EiZ.2016.007

\title{
Projekt uczelnianej aplikacji mobilnej dla studentów Państwowej Wyższej Szkoły Zawodowej we Włocławku „PWSZ”
}

\author{
Design of mobile application for students of \\ State Higher Vocational School in Włocławek „PWSZ”
}

\begin{abstract}
Streszczenie:
Artykuł zwraca uwagę na problem dotyczący dostarczania aktualnych informacji studentom. W rezultacie zostaje przedstawiona wieloplatformowa aplikacja mobilna - „PWSZ”. W artykule zostały opisane wymagania funkcjonalne, problematyka i zakres prac oraz technologie i narzędzia użyte podczas tworzenia oprogramowania. Ukazana została struktura bazy danych aplikacji. Praca podkreśla istotność skrupulatnie wybranych metod i konsultowania wyników pracy z klientem, by odpowiednio zrealizować wymagania użytkownika.
\end{abstract}




\section{Abstract:}

The article concentrates on the problem of providing actual information for students. As a result we present cross-platform mobile application - „PWSZ”. Article contains functional requirement, issues, list of tasks and technologies with tools used to implement software. We presents the structure of the database used in our application. The work highlights the importance of carefully selected methods and results of consulting work with the client to properly fulfil his requirements.

Słowa kluczowe: aplikacja mobilna PWSZ; wieloplatformowa uczelniana aplikacja mobilna; aplikacja uczelniana na telefon komórkowy; dostęp do informacji o uczelni poprzez mobilne urządzenie; mobilny organizer studenta „PWSZ”

Keywords: mobile application PWSZ; cross-platform mobile application for university; application for university on phone, information access; information availability for university through a mobile device; mobile organizer for student „PWSZ”

\section{Wprowadzenie}

Zaczyna się nowy etap komunikacji pomiędzy Państwową Wyższą Szkołą Zawodową we Włocławku a jej studentami. To już nie czas ciągłego lub regularnego siedzenia przed komputerem bądź patrzenia na telefon komórkowy w celu sprawdzenia aktualnych informacji na uczelnianej witrynie. Rozpoczęła się era mobilności. Aplikacja „PWSZ” pozwala na uzyskanie potrzebnych wiadomości w łatwy i przyjemny sposób. Nie trzeba posiadać specjalistycznej wiedzy informatycznej, aby obsługiwać w/w oprogramowanie. Za pomocą proponowanej aplikacji każdy człowiek będzie w stanie natychmiast uzyskać informację o zaistniałych zmianach, m.in. w terminie dyżuru, kolokwium, egzaminu, o odwołaniu zajęć lub aktualizacji planu.

Z aplikacji może skorzystać każda pojedyncza osoba, będąca właścicielem telefonu komórkowego z systemem Android, IOS oraz Win- 
dows Phone. Warunkiem koniecznym do użycia wszystkich funkcjonalności aplikacji jest stałe lub dorywcze łącze internetowe.

Głównym celem studentów informatyki PWSZ we Włocławku jest dotarcie w jak najprostszy sposób do współczesnego studenta. Pragną to zrobić poprzez jego telefon, ponieważ większość ludzi nie rozstaje się z nim nawet na chwilę. Studenci informatyki w rozwiązaniach mobilnych upatrują szans na efektywny dialog osób uczących się z uczelnianym ekosystemem i budowanie wizerunku instytucji, która idzie $\mathrm{z}$ duchem czasu.

Wszyscy potencjalni użytkownicy będą mieli możliwość przetestowania i oceny kilku aplikacji o podobnych funkcjonalnościach, tak, aby przyszłe dostępne oprogramowanie było jak najbardziej dostosowane do ich potrzeb.

Studenci będą wystawiać oceny aplikacjom według niżej przedstawionych kryteriów:

- łatwość obsługi,

- intuicyjność i prostota interfejsu użytkownika,

- ilość posiadanych funkcji,

- $\quad$ szybkość i skuteczność działania aplikacji.

W dalszej części artykułu przedstawiona zostanie problematyka i zakres pracy oraz kilka wybranych funkcjonalności aplikacji „PWSZ”. Zademonstrowane będą narzędzia, technologie oraz metody, z których skorzystamy, aby opracować tego typu projekt.

Rys. 1. Logo aplikacji „PWSZ”.

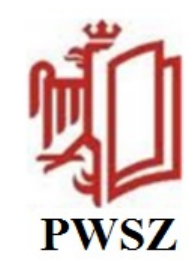




\section{Problematyka i zakres prac}

Niniejsza praca dotyczy zakresu technologii baz danych i inżynierii oprogramowania. Głównym przedmiotem pracy jest opracowanie, przeanalizowanie i zaprojektowanie oprogramowania pt. PWSZ.

Na swoje aplikacje mobilne zdecydowały się dotąd nieliczne uczelnie wyższe w kraju, m.in. Akademia Leona Koźmińskiego, Uniwersytet Ekonomiczny w Poznaniu, Wrocławiu oraz w Krakowie, Politechnika Łódzka i Wrocławska, Szkoła Główna Handlowa w Warszawie, Uniwersytet w Białymstoku. W znaczącej większości uniwersytetów i szkół wyższych komunikacja ze studentami odbywa się w bardziej tradycyjny sposób.

Najlepszy dowód na to, że inwestycje w nowe technologie są potrzebne także w placówkach szkolnictwa wyższego, stanowią opinie studentów, którzy uznają aplikację za pomocną. Zestawienie procentowe osób korzystających z aplikacji przenośnej zostało umieszczone poniżej [1].

Rys. 2. Wykres przedstawiający użytkowanie uczelnianej aplikacji przez studentów na przykładzie Akademii Leona Koźmińskiego.

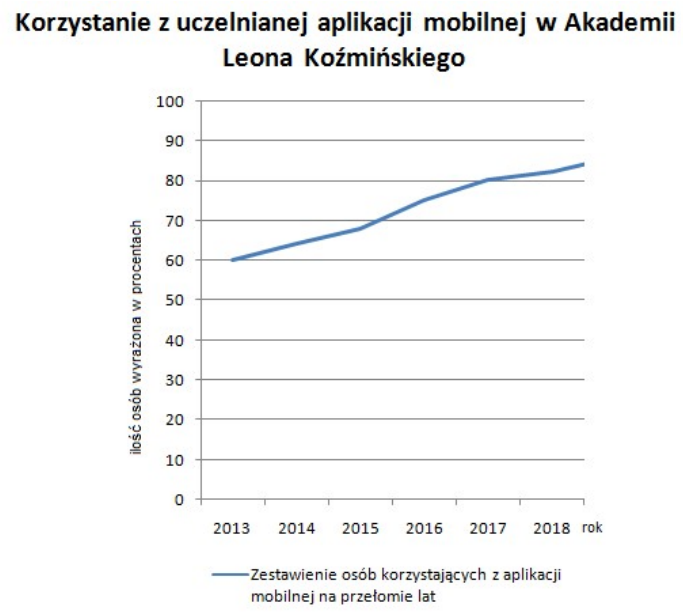

Źródło: opracowanie własne. Dane zebrane do sporządzenia wykresu zostały zaczerpnięte ze strony internetowej pod adresem: [1]. 
Na używanie uczelnianej aplikacji mogły wpłynąć takie czynniki jak:

- wzrost liczby użytkowników korzystających z telefonów komórkowych (więcej informacji na ten temat można znaleźć w [2]),

- atrakcyjne cenowo oferty smartfonów,

- coraz większa popularność telefonów komórkowych nowej generacji, m.in. dlatego, że wśród ofert operatorów sieci komórkowych przeważają smartfony [2],

- wzrost świadomości polskich konsumentów na temat telefonów nowej generacji (więcej informacji na ten temat można znaleźć $\mathrm{w}$ [3]),

- zwiększająca się liczba posiadaczy smartfonów korzystających $\mathrm{z}$ aplikacji mobilnych (więcej informacji na ten temat można znaleźć w [3]).

Analitycy Gartnera prognozują, że w 2018 r. sprzedaż smartfonów (która wpływa pozytywnie na ilość osób korzystających z aplikacji) wzrośnie aż do 88\% (więcej informacji na ten temat można znaleźć w [4]). Byłoby więc dobrze, aby uczelnie ubiegające się o wysokie pozycje w rankingach liderów oświaty dbały również o wysokie pozycje w mądrym wykorzystywaniu nowych technologii, które są w rękach ich studentów [1]. Dlatego też podjęliśmy się stworzenia oprogramowania, które umożliwi studentom efektywną wymianę informacji z uczelnią oraz umocni nowoczesny wizerunek PWSZ we Włocławku.

\section{Technologie i metody użyte w tworzeniu aplikacji}

W przypadku większości aplikacji napisanie oprogramowania wymaga połączenia $\mathrm{z}$ bazą danych oraz serwerem. Zaplanowany projekt będzie ponadto korzystał z następnej generacji usług sieciowych WCF. Baza danych to zbiór informacji zapisanych zgodnie z ustalonymi regułami. Język SQL (ang. Structured Query Language) to mechanizm umożliwiający odczytywanie danych z bazy. Zapytań SQL 
używamy do określenia, jakie dane mają zostać odczytane z bazy. Dane w bazie danych są uporządkowane w postaci tabel.

Tabele składają się z elementów tworzących logiczną grupę. W stworzonej aplikacji został użyty prosty obiekt zawierający wiadomości m.in. o wydawanych pieniądzach. Poszczególne rozchody są opisane za pomocą takich pól jak identyfikator rozchodu, kwota, data, miejsce sfinansowania i inne.

Tabele danych możemy traktować jako struktury posiadające wiersze i kolumny. Kolumny spełniają rolę podobną do nagłówków w arkuszu kalkulacyjnym. Nazwa kolumny w ramach tabeli musi być unikalna. Wiersze reprezentują poszczególne rekordy danych.

Serwerem natomiast jest komputer bądź program udostępniający zasoby innym programom bądź komputerom podłączonym do sieci (np. Internetu lub sieci lokalnej). Przykładami udostępnianych zasobów są pliki, bazy danych, łącza internetowe, a także urządzenia peryferyjne, takie jak drukarki i skanery [5].

Usługa sieciowa (ang. web service) to realizowana programistycznie usługa świadczona za pomocą sieci telekomunikacyjnej, a w tym sieci komputerowej, w szczególności przez Internet.

Usługa internetowa jest niezależną częścią oprogramowania od platformy sprzętowej oraz języka programowania, w jakim jest sporządzona określona funkcjonalność [6]. Usługa sieciowa jest jednym z rozwiązań problemu połączenia elementów tak, aby mogły komunikować się ze sobą oraz współpracować. Pozwala ona na integrację systemów informatycznych różnych przedsiębiorstw, co ułatwia szereg czynności związanych z funkcjonowaniem firm. Jednym z przykładów może być możliwość sprawdzenia w różnych hotelach wolnych pokoi i ich ilości przez przedsiębiorstwo [7].

Zgodnie $\mathrm{z}$ wytycznymi W3C dane powinny być przekazywane za pomocą protokołu HTTP oraz z wykorzystaniem XML [8].

Usługami sieciowymi są m.in. usługi WWW, poczta elektroniczna, usługi terminalowe, serwisy informacyjne, synchronizacja czasu lub dostęp do informacji o użytkownikach [9]. 
Aby napisać program na urządzenie mobilne, powinniśmy wybrać m.in. odpowiedni język programowania, system zarządzania bazą danych i serwer internetowy. Każdą aplikację można wykonać na kilka sposobów, w zależności od jej funkcjonalności oraz sposobu jej wykorzystania. Poniżej zostało przedstawionych oraz opisanych kilka wybranych narzędzi, którymi posłużymy się podczas implementacji programu. Stworzone oprogramowanie będzie można uruchomić na systemach: IOS, Android oraz Windows Phone. Jednym z głównych zamierzeń projektu była wieloplatformowość. Zależało nam, aby z aplikacji mogła skorzystać jak największa liczba studentów.

Tab. 1. Technologie oraz narzędzia użyte podczas tworzenia aplikacji „PWSZ”.

\begin{tabular}{|l|l|}
\hline \multicolumn{2}{|c|}{ Aplikacja wieloplatformowa } \\
\hline System zarządzania bazami danych & SQL Server \\
\hline Język programowania & C\# \\
\hline $\begin{array}{l}\text { Narzędzie służące do łatwego } \\
\text { zarządzania bazą danych }\end{array}$ & SQL Server 2014 Management Studio \\
\hline Środowisko zintegrowane & $\begin{array}{l}\text { Visual Studio 2015 z dodatkiem } \\
\text { Xamarin }\end{array}$ \\
\hline Generacja usługi sieciowej & $\begin{array}{l}\text { Windows Communication } \\
\text { Foundation }\end{array}$ \\
\hline Platforma programistyczna & .NET Framework \\
\hline $\begin{array}{l}\text { Zbiór technologii opartych na } \\
\text { Microsoft .NET Framework. }\end{array}$ & ASP.NET \\
\hline Serwer internetowy & IIS \\
\hline
\end{tabular}

Źródło: opracowanie własne.

\subsection{System zarządzania bazą danych: SQL Server}

(więcej informacji na ten temat można znaleźć w [10])

Wybraliśmy SQL Server, ponieważ:

- ma obszerną i dostępną dla wszystkich dokumentację,

- jest wysoko wydajnym, stabilnym i technologicznie dojrzałym produktem, 
- łatwo go zainstalować, posiada wsparcie na większości wersji SO Windows,

- w łatwy sposób można dokonać archiwizacji, ograniczenia praw dostępu, przetwarzania transakcyjnego, replikacji, itd.,

- może być wykorzystany przez projektanta do wytwarzania i rozruchu aplikacji, która następnie zostanie uruchomiona u klienta z wykorzystaniem MS SQL Serwera albo MS SQL Serwer Express [11],

- łatwo dokonać zmian w konfiguracji,

- posiada elastyczność w dziedzinie skalowania.

Całe środowisko może działać na jednym dużym serwerze lub skalować się w ramach farmy mniejszych [12]. Jest ciągle rozwijany przez Microsoft. Wkrótce będzie wspierał system operacyjny Linux. Posiada kontrole danych dowolnego typu. Pozwala na zarządzanie min. danymi relacyjnymi i nierelacyjnymi, danymi XML, zewnętrznymi dokumentami i plikami.

\subsection{Język programowania: C\#}

(więcej informacji na ten temat można znaleźć w [13])

Język programowania C\# został określony, jako spełniający wymagania konstrukcyjne projektu, ponieważ:

- C\# definiuje System obsługi języka Czasu Rzeczywistego, Common Language Runtime jest częścią .NET Framework, która umożliwia wieloplatformowość, obsługuje wielojęzykowość,

- tworzy zarządzany kod, co przyczynia się do nowoczesnego zarządzania pamięcią, zdolności mieszania się języków programowania oraz kontroli wersji projektów,

- pozwala na przygotowanie aplikacji sieciowych rozszerzających funkcjonalność serwerów WWW (po przez wykorzystanie biblioteki ASP.NET) [14], 
- zapewnia bezpieczeństwo - zarówno w znaczeniu stabilności systemu, jak i zapewnienia bezpieczeństwa aplikacji sieciowych poprzez ochronę przed atakami [15].

3.3 Narzędzie służące do łatwego zarządzania bazą danych: SQL Server 2014 Management Studio

(więcej informacji na ten temat można znaleźć w [16])

Wybraliśmy SQL Server Management Studio, ponieważ:

- jest to bezpłatne i łatwe w obsłudze narzędzie,

- umożliwia budowę zapytań i skryptów, zawiera zarówno edytor skryptów jak i narzędzia graficzne,

- zawiera narzędzia do konfiguracji, monitorowania i administrowania instancjami SQL Server.

\section{4 Środowisko zintegrowane: Visual Studio 2015 z dodatkiem} Xamarin

(więcej informacji na ten temat można znaleźć w [17])

Wybraliśmy Visual Studio, ponieważ posiada:

- IntelliSense: podpowiadanie składni, inteligentne kończenie fragmentów kodu, szablony kodu, weryfikacja spójności kodu na żywo, analiza zmiennych i wiele innych,

- w pełni funkcjonalny debugger,

- rozbudowany edytor kodu (kolorowanie składni, opcje edycyjne) [18],

- dodatek Xamarin, który umożliwia tworzenie wieloplatformowych aplikacji w C\#.

3.5 Generacja usługi sieciowej: Windows Communication Foundation (więcej informacji na ten temat można znaleźć w [19])

Wybraliśmy WCF, ponieważ:

- usługi sieciowe w następnej generacji usług sieciowych są wszechstronne, 
- niezależnie od protokołu komunikacji czy technologii sposób budowy protokołu jest ten sam,

- WCF integruje i unifikuje wszystkie dotychczasowe technologie Microsoftu służące do komunikacji [20].

\subsection{Serwer internetowy: IIS}

(więcej informacji na ten temat można znaleźć w [21])

Wybraliśmy IIS, ponieważ:

- jest drugim co do popularności serwerem stron internetowych na świecie,

- zostały usunięte wszystkie sygnalizowane przez ekspertów usterki związane z bezpieczeństwem (w wersji 6.0) [22].

\subsection{Platforma programistyczna: .NET Framework}

(więcej informacji na ten temat można znaleźć w [23])

Wybraliśmy .NET Framework, ponieważ:

- w środowisku tym można tworzyć oprogramowanie działające po stronie serwera internetowego (IIS) oraz pracujące na systemach, na które istnieje działająca implementacja tej platformy,

- technologia ta związana jest m.in. z językiem programowania C\#,

- zarządza różnymi elementami systemu: kodem aplikacji, pamięcią i zabezpieczeniami [24].

3.8 Zbiór technologii opartych na Microsoft .NET Framework: ASP.NET (więcej informacji na ten temat można znaleźć w [25])

Wybraliśmy ASP.NET, ponieważ:

- jest wspierany przez separujący warstwę logiki od warstwy prezentacji wątkowo-kierowany model programistyczny, co poprawia wydajność działania aplikacji,

- logika stron ASP.NET oraz XML Web Services może być tworzona $\mathrm{w}$ dowolnym języku wspierającym technologię Microsoft .NET Framework [26]. 


\section{Funkcjonalności, jakie posiada aplikacja}

\section{Wymagania funkcjonalne po stronie klienta:}

Tab. 2. Wymagania funkcjonalne systemu po stronie klienta dla aplikacji mobilnej z podziałem na grupy użytkowników (odpowiednia uprawnienia): użytkownik zarejestrowany oraz użytkownik niezarejestrowany. Źródło: opracowanie własne.

\begin{tabular}{|c|c|}
\hline Użytkownik zarejestrowany & $\begin{array}{l}\text { Użytkownik } \\
\text { niezarejestrowany } \\
\text { (gość) }\end{array}$ \\
\hline Możliwość logowania się i rejestracji. & Możliwość rejestracji. \\
\hline $\begin{array}{l}\text { Wyświetlenie powiadomień o: } \\
\text { - } \quad \text { odwołaniu zajęć, dyżurów, } \\
\text { - } \quad \text { terminach zastępstw wykładowców, zaliczeniach lub } \\
\text { egzaminie w sesji, } \\
\text { - } \quad \text { terminach wydarzeń, imprez okolicznościowych (np. } \\
\quad \text { juwenalia), składania indeksów, złożenia dokumen- } \\
\text { tów do stypendium socjalnego i stypendium rektora } \\
\text { dla najlepszych studentów. }\end{array}$ & \\
\hline $\begin{array}{l}\text { Wyświetlenie wiadomości z zakładki ze strony uczelni } \\
\text { „Informacje dla studentów”. }\end{array}$ & $\begin{array}{l}\text { Wyświetlenie informa- } \\
\text { cji o autorze. }\end{array}$ \\
\hline $\begin{array}{l}\text { Ukazanie oraz wytyczenie najkrótszej trasy do budynków } \\
\text { dydaktycznych uczelni. }\end{array}$ & \\
\hline Wyświetlenie informacji o autorach. & \\
\hline $\begin{array}{l}\text { Ukazanie planu zajęć w zależności od: wybranej daty, prze- } \\
\text { działu czasowego, specjalizacji, grupy oraz roku. Dane } \\
\text { domyślnie są uzupełnione informacjami o poszczególnym } \\
\text { użytkowniku. }\end{array}$ & \\
\hline $\begin{array}{l}\text { Wyszukiwarka pozwalająca ujrzeć, w której sali ma dany } \\
\text { rok zajęcia. }\end{array}$ & \\
\hline Przedstawienie planu uczelni z oznaczonymi salami. & \\
\hline $\begin{array}{l}\text { Skorzystanie z kalendarza, który pozwala na wprowadzanie } \\
\text { i tworzenie powiadomień przez użytkownika. Ma to na celu } \\
\text { przypomnieć klientowi o terminach w sesji bądź kolokwiach. }\end{array}$ & \\
\hline $\begin{array}{l}\text { Ukazanie przydatnych kontaktów dla studenta umieszczo- } \\
\text { nych na stronie uczelni (e-mail i numer telefonu). }\end{array}$ & \\
\hline $\begin{array}{l}\text { Wyświetlanie aktualnych stałych zniżek i promocji dla } \\
\text { studentów. }\end{array}$ & \\
\hline Ukazanie podziału roku akademickiego w postaci tabeli. & \\
\hline Wyświetlenie panelu z ustawieniami. & \\
\hline
\end{tabular}


Wyświetlanie powiadomienia będą cały czas dostosowywane do zaznaczonych opcji w ustawieniach i aktualizowane. Notyfikacje widnieją przez 2 dni na pasku stanu urządzenia lub do chwili kliknięcia $\mathrm{w}$ powiadomienie.

Wyświetlenie wiadomości z zakładki ze strony uczelni „Informacje dla studentów". Zostanie zaimplementowany algorytm wyszukujący wybrane słowa $\mathrm{w}$ ogłoszeniu związane $\mathrm{z}$ danym kierunkiem. W rezultacie zostaną odfiltrowane tylko te informacje, które nas interesują.

Po stronie administratora - administrator nie dziedziczy uprawnień po grupach: użytkownik zarejestrowany oraz użytkownik niezarejestrowany. Administrator nie może ujrzeć i modyfikować haseł klientów. W ten sposób unikamy nadmiernej inwigilacji. W tabeli odpowiedzialnej za przetrzymywanie informacji o użytkowniku nie ma możliwości dokonywania zmian. Zajmuje się zarządzaniem serwerem. Administrator posiada pełny dostęp do wszystkich danych na serwerze.

Po stronie projektanta - projektant tworzy nowe tabele, widoki, przechowywane procedury. Potrzebuje dostępu do wszystkich obiektów. Projektant ma pełny dostęp do bazy danych. 


\section{Struktura bazy danych}

W systemie występuje lokalna baza danych

Rys. 3. Fragment struktury bazy danych aplikacji „PWSZ”.

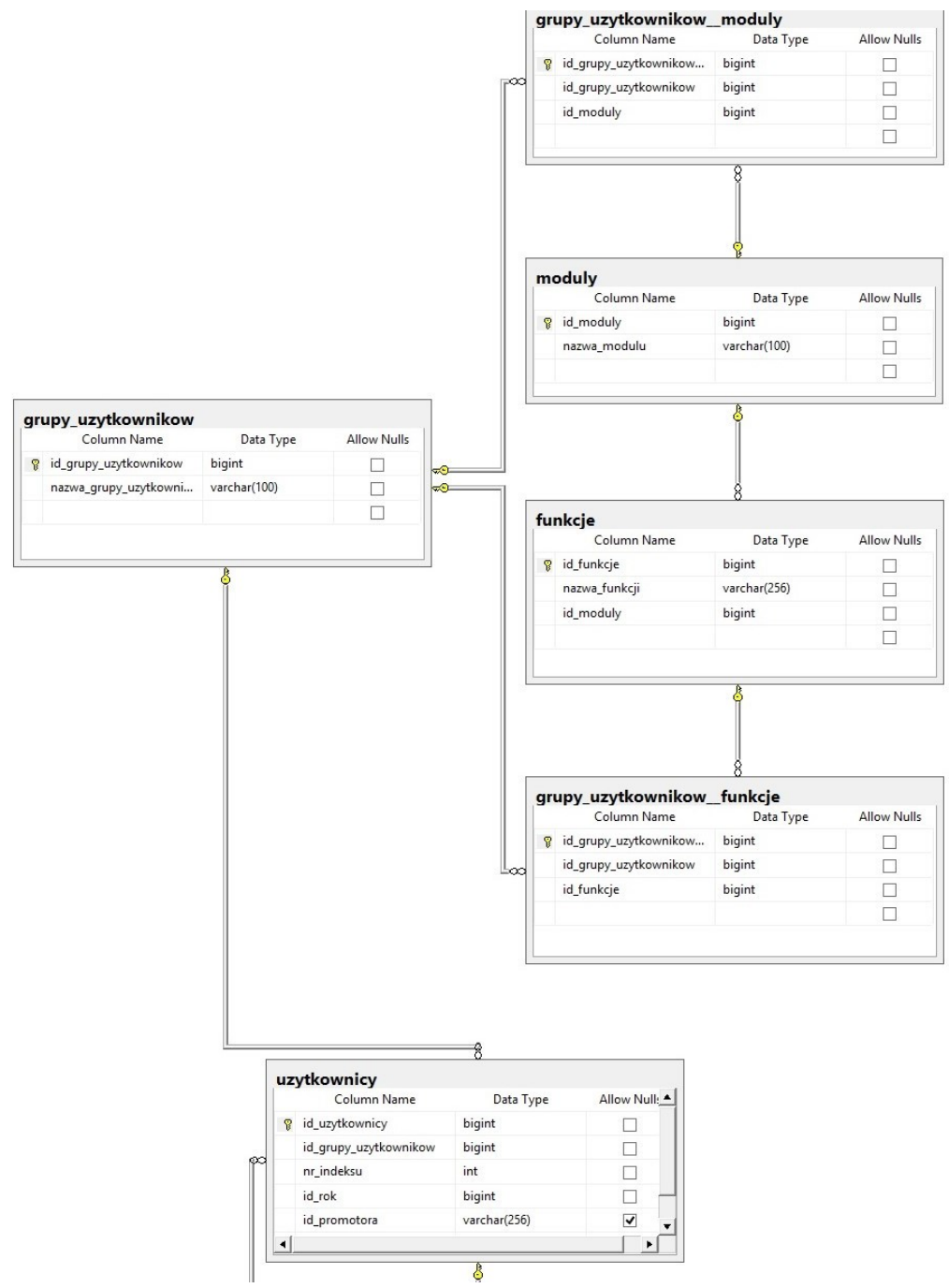

Źródło: opracowanie własne. 


\section{Interfejs użytkownika}

Rys. 4. Projekt interfejsu użytkownika ukazujący ekran startowy aplikacji. Interfejs wykonany został wykonany za pomocą kreatora dostępnego pod adresem: https://www.humblebundle.com.

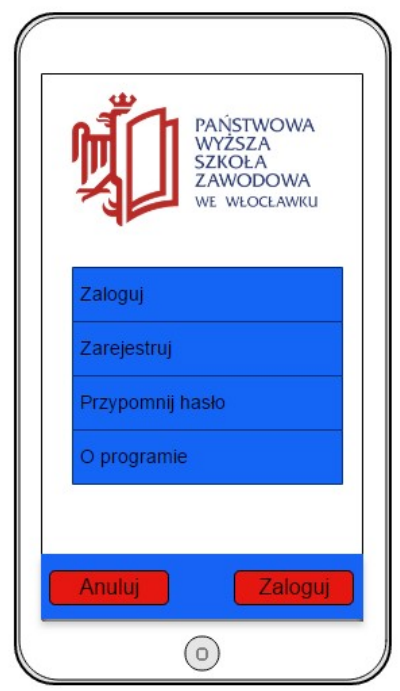

Źródło: opracowanie własne (przy pomocy strony: https://www.humblebundle.com).

Rysunek 4. Przedstawia ekran startowy aplikacji „PWSZ”. Znajduje się na nim moduł logowania użytkownika. W przypadku, gdy użytkownik nie posiada konta w aplikacji, może je stworzyć po naciśnięciu przycisku „Zarejestruj”. Jeśli klient nie pamięta hasła do swojego konta użytkownika, ma do dyspozycji opcję „Przypomnij hasło”. Po przyciśnięciu guzika „O programie” klientowi ukażą się informację dotyczące funkcjonalności aplikacji oraz wiadomości o autorach. 
Rys. 5. Wizualizacja interfejsu użytkownika panelu logowania. Interfejs został wykonany za pomocą kreatora dostępnego pod adresem: https://www.humblebundle.com.

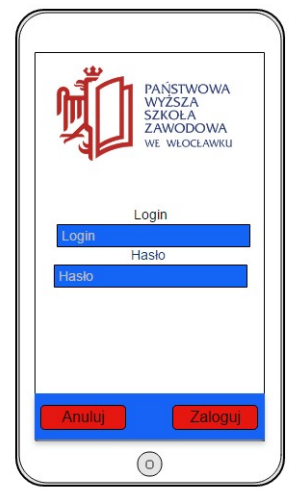

Źródło: opracowanie własne (przy pomocy strony: https://www.humblebundle.com).

Rysunek 5 ukazuje panel logowanie użytkownika. Osoba korzystająca z aplikacji ma możliwość powrotu do ekranu startowego oprogramowania poprzez przyciśnięcie guzika „Anuluj” bądź zalogowanie się po poprawnym wprowadzeniu loginu i hasła oraz wciśnięcie przycisku „Zaloguj”.

Rys. 6. Ukazanie GUI po poprawnym zalogowaniu użytkownika. Interfejs został wykonany za pomocą kreatora dostępnego pod adresem: https://www.humblebundle.com.

Źródło: opracowanie własne (przy pomocy strony: https://www.humblebundle.com).

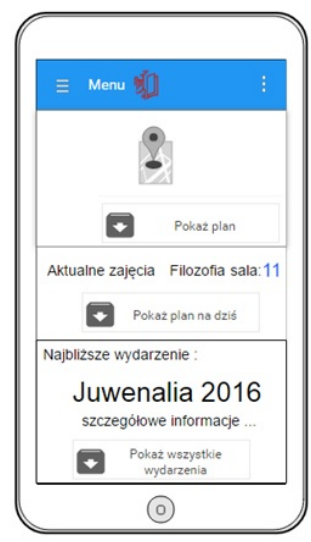


Rysunek 6 pokazuje interfejs graficzny użytkownika po poprawnym zalogowaniu klienta. Student może ujrzeć informację o aktualnie odbywających się zajęciach, wyświetlić plan zajęć na dzień, w którym go oglądamy. Poprzez wciśnięcie przycisku „Pokaż plan” użytkownikowi ukażą się opcje wyboru, gdzie będzie mógł zadecydować, według jakich kryteriów ma zostać wyświetlony plan zajęć (np. konkretna data, grupa, kierunek). Na samej górze widnieje przycisk, który przenosi użytkownika do modułu odpowiadającego za wyznaczenie trasy do wybranego budynku dydaktycznego PWSZ we Włocławku. Na samym dole interfejsu użytkownika widnieją „Najbliższe wydarzenia”, czyli powiadomienia, które zapisał klient w kalendarzu aplikacji.

Rys. 7. Planowany wygląd zmiany ustawień w aplikacji dotyczący powiadomień. Interfejs został wykonany za pomocą kreatora dostępnego pod adresem: https://www.humblebundle.com.

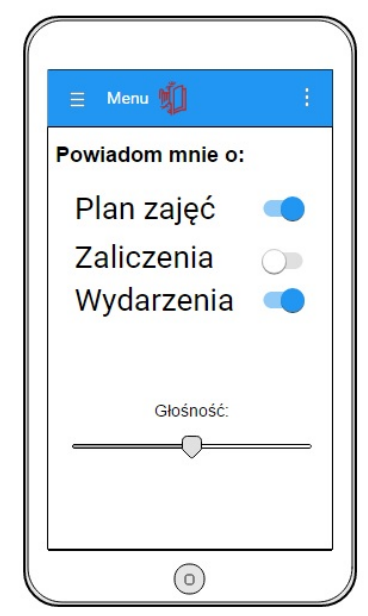

Źródło: opracowanie własne (przy pomocy strony: https://www.humblebundle.com). 
Rys. 8. Planowany interfejs użytkownika ukazujący plan zajęć w zależności od wybranej daty. Interfejs został wykonany za pomocą kreatora dostępnego pod adresem: https://www.humblebundle.com.

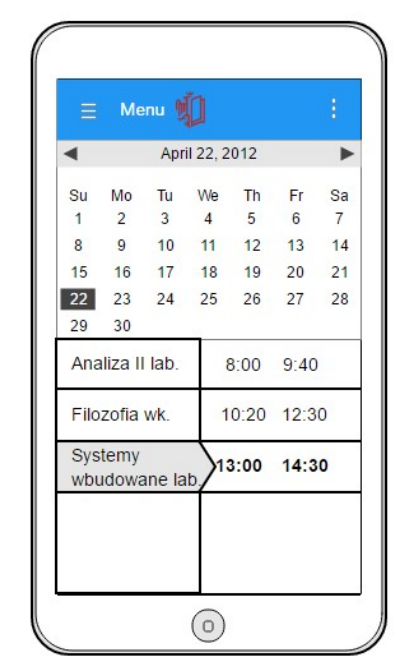

Źródło: opracowanie własne (przy pomocy strony: https://www.humblebundle.com).

\section{Wnioski i perspektywy dalszych prac}

Projektowane oprogramowanie zostało poprawnie zrealizowane i uruchomione na telefonie Samsung SM-G357FZ oraz emulatorze środowiska Android Nexus 5 API 23. Stwierdzono poprawną realizację wszystkich zamierzonych funkcji oprogramowania. Możliwe jest rozszerzenie funkcjonalności oprogramowania o:

- funkcję, która dostosowywałaby interfejs aplikacji dla osób słabo widzących,

- opcję, która pozwalałaby, aby plan zajęć był odczytany przez syntezator mowy. 


\section{Literatura:}

[1] http://interaktywnie.com/okiem-eksperta/nowoczesna-uczelnia-tomobilna-uczelnia-249890 (dostęp: 06.11.2016 r.).

[2] http://www.chip.pl/news/wydarzenia/statystyka/2015/01/juz-90proc.-polakow-korzysta-z-telefonow-komorkowych (dostęp: 06.11.2016 r.).

[3]http://jestem.mobi/2014/02/smartfonizacja-w-polsce-2014najwazniejsze-liczby-infografika/ (dostęp: 06.11.2016 r.).

[4] http://www.gartner.com/technology/about.jsp (dostęp: 06.11.2016 r.).

[5] M. Bartczak, Wybrane fazy cyklu projektowego aplikacji mobilnej do zarządzania budżetem domowym „e-portmonetka”, [w:] M. Wiśniewska (red.), Wyzwania gospodarcze, polityczne $i$ społeczne $w$ globalnej gospodarce, Wydawnictwo Państwowej Wyższej Szkoły Zawodowej, Włocławek 2016.

[6] https://pl.wikipedia.org/wiki/Us\%C5\%82uga_internetowa\#cite_note-1 (dostęp: 06.01.2016 r.).

[7] http://www.cs.put.poznan.pl/mzakrzewicz/pubs/ploug06sec.pdf (dostęp: 06.01.2016 r.).

[8] https://www.w3.org/TR/ws-gloss/\#webservice (dostęp: 06.01.2016 r.).

[9]http://smurf.mimuw.edu.pl/external_slides/W12_Uslugi_sieciowe/Uslugi _sieciowe_M12.html (dostęp: 06.11.2016 r.).

[10] https://www.microsoft.com/pl-pl/server-cloud/products/sqlserver/overview.aspx (dostęp: 06.11.2016 r.).

[11] https://www.promotic.eu/pl/pmdoc/Subsystems/Db/MsSQL/Install.htm (dostęp: 06.11.2016 r.).

[12] https://msdn.microsoft.com/pl-pl/library/sql-server-wstep.aspx (dostęp: 06.11.2016 r.).

[13] https://msdn.microsoft.com/pl-pl/library/67ef8sbd.aspx (dostęp: 06.11.2016 r.).

[14] http://pusiu.republika.pl/ogolne.html (dostęp: 07.11.2016 r.).

[15] http://www.pcworld.pl/news/314604/Cztery.plusy.html (dostęp: 07.11.2016 r.). 
[16] https://msdn.microsoft.com/en-us/library/mt238290.aspx (dostęp: 06.11.2016 r.).

[17] https://www.xamarin.com/ (dostęp: 14.11.2016 r.).

[18] http://www.dobreprogramy.pl/Visual-C,Program,Windows,12108.html (dostęp: 13.11.2016 r.).

[19] https://msdn.microsoft.com/pl-pl/library/ms731082(v=vs.110).aspx (dostęp: 14.11.2016 r.).

[20] https://pl.wikipedia.org/wiki/Windows_Communication_Foundation (dostęp: 13.11.2016 r.).

[21] https://www.iis.net/ (dostęp: 14.11.2016 r.).

[22] https://pl.wikipedia.org/wiki/Internet_Information_Services (dostęp: 12.11.2016 r.).

[23] https://www.microsoft.com/pl-pl/download/details.aspx?id=30653 (dostęp: 14.11.2016 r.).

[24] https://pl.wikipedia.org/wiki/.NET_Framework (dostęp: 13.11.2016 r.).

[25] https://www.asp.net/ (dostęp: 14.11.2016 r.).

[26] https://pl.wikipedia.org/wiki/ASP.NET (dostęp: 12.11.2016 r.).

[27] https://www.humblebundle.com (dostęp: 12.11.2016 r.). 